\title{
The value of royalty
}

\author{
Michael A Reslinski \& Bernhard S Wu \\ Academic institutions need to prioritize how they incorporate terms for royalty streams into license agreements.
}

\begin{abstract}
ntellectual property (IP) license agreements are critical to commercializing academic discoveries. There are, however, always substantial challenges facing inventors and technology transfer offices (TTOs) seeking to enter into fair agreements with commercial partners $^{1}$. Inventors and TTOs negotiating license agreements with corporate partners have multiple levers that can be used to arrive at a winning deal that shares both risks and rewards. Structuring deals that align interests will incentivize parties to work collaboratively and avoid disputes over economics, which have become more common and can take years and major expenditures to resolve ${ }^{2}$. It is also increasingly common for startups to in-license and initially develop a technology and then subsequently enter into a sublicense or other collaborative agreement with a third party to further develop the asset. This increases the complexity and potential risks associated with license agreements ${ }^{2}$. We address each of these issues in this paper.
\end{abstract}

As a third-party private equity investor focused on the purchase of biopharmaceutical royalties based on licensed IP, we have over many years observed remarkable economic wealth generated from licensing. Sadly, we have also witnessed a number of stunning, even frightening, disappointments where licensors have not realized the benefits of IP licensing. This article highlights the key features of license agreements, especially those that increase the alignment between licensor and licensee and that thereby maximize economic value for each party. We outline the importance of royalty payments as a form of compensation to licensors and highlight several common traps that we have encountered in reviewing hundreds of license agreements

Michael A. Reslinski \& Bernhard S. Wu are at DRI Capital, Toronto, Ontario, Canada. e-mail:bw@dricapital.com

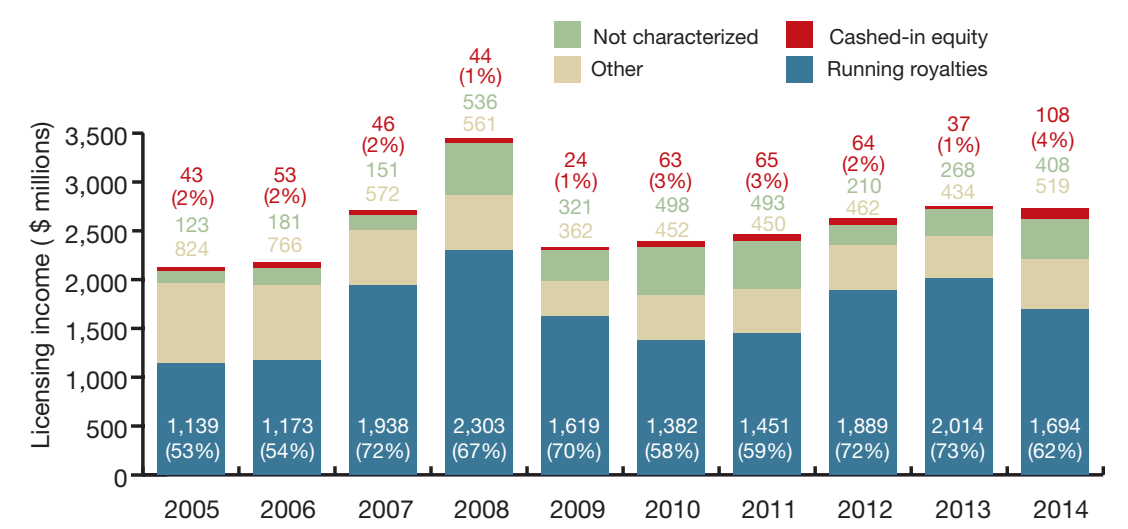

Figure 1 Breakdown of gross licensing income for all universities that submitted data as part of the AUTM Licensing Survey. Income broken down into royalties, cashed-in equity, other, and notcharacterized. Also given, running royalties and cashed-in equity as a percentage of total licensing income. Source: 2014 AUTM Licensing Survey.

between academic institutions and their partners, including both startups and more established biotech and pharmaceutical companies.

\section{Compensation in license agreements}

License agreements provide several types of economic compensation, including equity (in the licensee), upfront payments, milestone payments, and royalties. Each has unique benefits and risks (Table 1).

In considering the optimal compensation structure, it is useful to bear in mind the primary objective of the licensee. The primary objective of a licensee typically is to arrive at the next value-creating inflection point, while also minimizing expenses and sharing risk with the licensor. Risks to successful commercialization are high. As our analysis reveals, only a small proportion of licensed technologies ever generate meaningful revenue. Therefore, although there is a natural tension between licensor and licensee with respect to upfront versus contingent payments, licensors often underestimate the upfront risks and costs licensees assume. At the same time, licensees typically are willing to provide meaningful economic compensation in the form of royalties, which are contingent upon successful commercialization (making royalties a flexible form of downstream economic compensation).

TTOs are often forced to make a difficult trade-off between securing near-term revenue in order to manage operating expenses, and maximizing long-term licensing income. Budgetary pressures are a powerful incentive in favor of upfront payment. However, we believe that royalties maximize long-term value and alleviate future fiscal constraints. Evidence suggests that the majority of wealth generated from IP is in the form of royalties.

\section{Royalty payments}

In addition to being a flexible form of economic compensation in license agreements, royalty payments have been the most economically meaningful. Based on the last ten years of data submitted by US universities as part of the annual Association of University Technology Managers' (AUTM; Oakbrook Terrace, IL, USA) 'Licensing Survey', in all years since 2005, 


\begin{tabular}{|c|c|c|c|}
\hline Type of compensation & & Licensor & Licensee \\
\hline \multirow[t]{4}{*}{ Equitya } & \multirow[t]{2}{*}{ Benefits } & $\begin{array}{l}\text { Captures some future value regardless of product's stage of } \\
\text { development }\end{array}$ & \multirow[t]{2}{*}{ Enables preservation of cash } \\
\hline & & $\begin{array}{l}\text { Probability of a liquidity event is higher as equity can be cashed in } \\
\text { before a company has a commercially successful product }\end{array}$ & \\
\hline & \multirow[t]{2}{*}{ Risks } & Equity can be illiquid and difficult to value & \multirow{2}{*}{$\begin{array}{l}\text { Equity issuances are dilutive and the value of licensed } \\
\text { IP contributing to the value of equity may be difficult to } \\
\text { ascertain }\end{array}$} \\
\hline & & $\begin{array}{l}\text { Institutions with equity in licensees that are university startups/ } \\
\text { spinouts will be diluted in subsequent financing rounds unless the } \\
\text { investment is upsized }\end{array}$ & \\
\hline \multirow[t]{3}{*}{ Upfront payment ${ }^{\mathrm{b}}$} & Benefits & $\begin{array}{l}\text { Payment received at earliest stage of development that captures } \\
\text { immediate value }\end{array}$ & $\begin{array}{l}\text { May enable reduction in other downstream economics by } \\
\text { offering more upfront and/or guaranteed compensation }\end{array}$ \\
\hline & \multirow[t]{2}{*}{ Risks } & $\begin{array}{l}\text { Downstream economics such as milestones and royalties may be } \\
\text { much more meaningful }\end{array}$ & $\begin{array}{l}\text { Cash payout is challenging if licensee is a small com- } \\
\text { pany/startup needing to conserve cash }\end{array}$ \\
\hline & & $\begin{array}{l}\text { Securing more upfront and/or guaranteed compensation typically } \\
\text { reduces long-term compensation, such as royalties }\end{array}$ & $\begin{array}{l}\text { Risk of overpayment given challenge of successfully } \\
\text { developing and commercializing a pharmaceutical } \\
\text { product }\end{array}$ \\
\hline \multirow[t]{3}{*}{ Milestone payment ${ }^{c}$} & \multirow[t]{2}{*}{ Benefits } & $\begin{array}{l}\text { Yields economic benefits as clinical, regulatory or commercial } \\
\text { milestones are met }\end{array}$ & \multirow[t]{2}{*}{$\begin{array}{l}\text { Enables preservation of cash until de-risking events } \\
\text { occur }\end{array}$} \\
\hline & & $\begin{array}{l}\text { Can be monetized to accelerate payments and mitigate some } \\
\text { clinical, regulatory and commercial risk }\end{array}$ & \\
\hline & Risks & $\begin{array}{l}\text { Milestone payouts are binary in nature and are difficult to design, } \\
\text { negotiate, and forecast }\end{array}$ & $\begin{array}{l}\text { Requires company to reserve cash for milestone payouts, } \\
\text { which can be difficult to predict }\end{array}$ \\
\hline \multirow[t]{3}{*}{ Royalties $^{d}$} & Benefits & $\begin{array}{l}\text { Aligns long-term interests of licensor and licensee } \\
\text { If based on a proportion of product sales, is not subject to inflation }\end{array}$ & \multirow[t]{2}{*}{$\begin{array}{l}\text { Mitigates risk of initial overpayment and enables preser- } \\
\text { vation of cash until product is commercialized }\end{array}$} \\
\hline & & $\begin{array}{l}\text { Can be monetized to accelerate payments and mitigate some } \\
\text { clinical, regulatory, and commercial risk }\end{array}$ & \\
\hline & Risks & $\begin{array}{l}\text { Typically used under assumption that product will be } \\
\text { commercialized within IP term }\end{array}$ & $\begin{array}{l}\text { Ongoing royalty payments to licensor will have negative } \\
\text { impact on profitability of product }\end{array}$ \\
\hline
\end{tabular}

aEquity includes transfer or issue of company shares from the licensee to the licensor. bUpfront payments include consideration paid by the licensee to the licensor following execution of the license agreement, and may include reimbursements for costs incurred. 'Milestone payments are lump sum payments triggered by specific clinical, legal, regulatory, or commercial

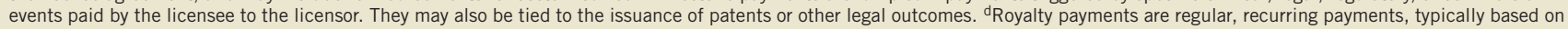
product sales, paid by the licensee to the licensor.

running royalties comprised the majority of gross licensing income (Fig. 1) ${ }^{3}$. In this data set, running royalties are defined as royalties earned on and tied to the sale of products. License issue fees, payments under options, termination payments, and the amount of annual minimums not supported by sales are excluded from this definition. In some years, running royalties comprised as much as $73 \%$ of total licensing income (Fig. 1). In contrast, over the past ten years, cashed-in equity never exceeded $4 \%$ of total licensing revenue (Fig. 1).

Although the AUTM data set does not segregate licensing income by sector, a 2013 Nature Biotechnology analysis of data submitted by TTOs revealed that among ten US universities with the highest gross licensing revenues, life sciences IP drove $>90 \%$ of the total gross licensing revenue ${ }^{4}$. Among top-performing institutions, life sciences IP is the primary driver of technology transfer economic output.

The top five institutions based on gross licensing income received in the AUTM survey were New York University, Columbia University, Memorial Sloan Kettering Cancer Center, Princeton University, and Stanford University. Analysis of the AUTM data revealed unique features specific to these five institutions. (Readers should note that AUTM data from both Northwestern University, which did not break out sources of licensing income, and the University of California and the University of Texas systems, which submitted data aggregated from multiple campuses, were excluded from this analysis). The impact of running royalties on gross licensing income received at these top-performing institutions (Fig. 2) was even more dramatic than that seen on average for all the institutions in the survey. At all five institutions, running royalties contributed the majority of gross licensing income. In the case of New York University, Columbia University, and Princeton University, running royalties comprised $>90 \%$ of gross licensing income.

In aggregate, among the top ten individual institutes based on gross licensing income received, royalties comprised $\sim 83 \%$ of total gross licensing income received in 2014. Put another way, the institutes that generated the most revenue from licensed patents did so through the receipt of royalty payments. Contrast this with the small number of licenses/ options that yield material income $>\$ 1$ million/ year at all US institutions. In 2014, there were only 223 licenses/options generating $>\$ 1$ million/year. In contrast 9,548 licenses/options generated royalties (Fig. 3). This highlights the risk that licensees bear when investing in new technologies.

This may lead some academic institutions to think that it is not worth asking for royalties because of the low probability of yielding material income. However, the data and our experience also suggest that licensees are typically much more open to royalties than to making upfront payments. Even singular successes in commercialization more than make up for licenses that fail to generate any revenue whatsoever.

To illustrate the point, we examined the top five TTOs with running royalties in terms of gross licensing income (Fig. 4). Fewer than ten license agreements at each of these institutions drive the majority of economic compensation received on an annual basis. At both New York University and Princeton University, just three licenses generated \$216 million and $\$ 143$ million in gross licensing income, respectively (Fig. 2). The scarcity of extremely valuable license agreements places substantial weight on the factors that drive licensing income. License agreement design, in particular with respect to royalty payments, needs to be carefully executed to preserve and maximize the potential future value of IP. 
Royalties are a flexible economic mechanism because they are paid when substantial research, clinical, and regulatory risks have passed, and the principal source of risk remaining is commercial uptake, including in multiple geographies and therapeutic areas ${ }^{5}$. A solid royalty arrangement ensures that both the licensee and licensor are incentivized to facilitate the ongoing development and commercialization of the life sciences asset in these areas. As such, both parties reap financial rewards when technological success is translated into stable and ongoing commercial demand for the product. In addition, royalty entitlements can be used to overcome information and experience asymmetries that inventors and academic institutions encounter when working with biotech and pharma companies, which will invariably have better insight into factors affecting clinical, regulatory, and marketing success. Equally important, a focus on the deferred nature of royalty income can streamline negotiations, shortening the time for an agreement with licensees. This reality may be particularly important in academic institutions which have complex decision-making processes and multiple stakeholders who naturally take a stronger interest in near-term economics ${ }^{1}$.

\section{Key considerations (beware the boiler plate)}

Royalty payments may seem like a simple compensation mechanism, but various factors can complicate their application in practice. Complexity can be managed, however, and several key factors related to royalty payments can be negotiated to structure mutually beneficial transactions (Fig. 5).

Basis of payment. A licensor needs to decide whether to grant an exclusive, non-exclusive, or sole license. These options involve one licensee, many licensees, or one licensee with certain rights being retained by the licensor, respectively. The choice of how broadly to license IP will in part determine compensation that the licensor may ultimately receive.

The scope of the rights granted to the licensee is essential in determining the potential future value of the license agreement. No royalties will be paid on a product if the licensee successfully argues the technology used was outside the scope of the license agreement.

Careful drafting of license agreements, in particular with respect to product definitions, can help prevent disputes between licensees and licensors.

Similarly, a license agreement should address improvements contributed by both the licensee and the licensor to the original technology. In many instances, the licensor will continue to develop the technology. The licensor will want to clarify the compensation it receives for these improvements, including potential next-generation products. The licensor will also want to ensure that the definition of licensed product contemplates improvements or, alternatively, to restrict the license grant such that the licensee will need to subsequently in-license any improvements ${ }^{6}$.

Well-drafted license agreements contemplate product usage scenarios that may not be immediately obvious. For example, oncology therapeutics are now frequently used in combination-treatment regimens. License agreements should specify a mechanism for calculating economic consideration for one or more possible combination products. Preemptively anticipating these usage scenarios may eliminate the need to renegotiate a license agreement at a future date, when the licensor may have much less leverage.

The term of a license agreement is often tied to expiration of the relevant out-licensed patents. To extend the life of royalty payments, it is common practice for licensors to license multiple patents with staggered expiration dates. Under this scenario, the licensee must pay royalties until the patent with the longest life expires $^{7}$. As such, it is critical to have a detailed understanding of both pending patent applications and issued patents as well as potential future patents that may have an impact on these future economics.

Know-how-based royalty entitlements provide licensors with potential income after patent expiration. However, the case of Brulotte vs. Thys Co. determined that "a patentee's use of a royalty agreement that projects beyond the expiration date of the patent is unlawful per $s e^{\text {"8,9 }}$. Importantly, the per se prohibition does not prevent licensors from licensing multiple patents and tying the royalty to the last-to-expire patent or clearly defining in a license agreement that post-patent payments are due for royalties earned during the prepatent-expiration period. From a licensor's perspective, the underlying license agreement should clearly state the rationale for any postpatent-expiration payments. Clearly spelling out that such post-patent-expiration payments are tied to non-patent value drivers (e.g., knowhow, provision of materials) and/or are tied to pre-patent-expiration activities (e.g., product manufacture), as well as the use of step-down provisions are ways to avoid any future challenges by the licensee to these post-patent expiry payment obligations.

License agreements based on limited territories are common ${ }^{6}$. For this reason, many license agreements restrict royalty payments to those geographies where patents have been granted. In such circumstances, it is essential that the definition of territory is clearly defined.

Payment mechanics. The licensor and licensee must agree to a reasonable basis for calculation of economic consideration. Royalties can be calculated in various ways, including for example, on the basis of gross receipts, net sales, or some metric related to volume of product sold (e.g., units sold). Most licensees will not agree to royalties based on gross receipts alone, as it is very typical to allow for deduction of certain reasonable expenses associated with commercialization of the product ${ }^{7}$. These deductible expenses usually include allowances for refunds, trade discounts and taxes, although we are seeing a substantial expansion of these licensee deductions following the arrival of new risk-sharing rebate arrangements in international markets, as well as licensee expenses associated with the implementation of the Affordable Care Act in the United States. It is possible that a
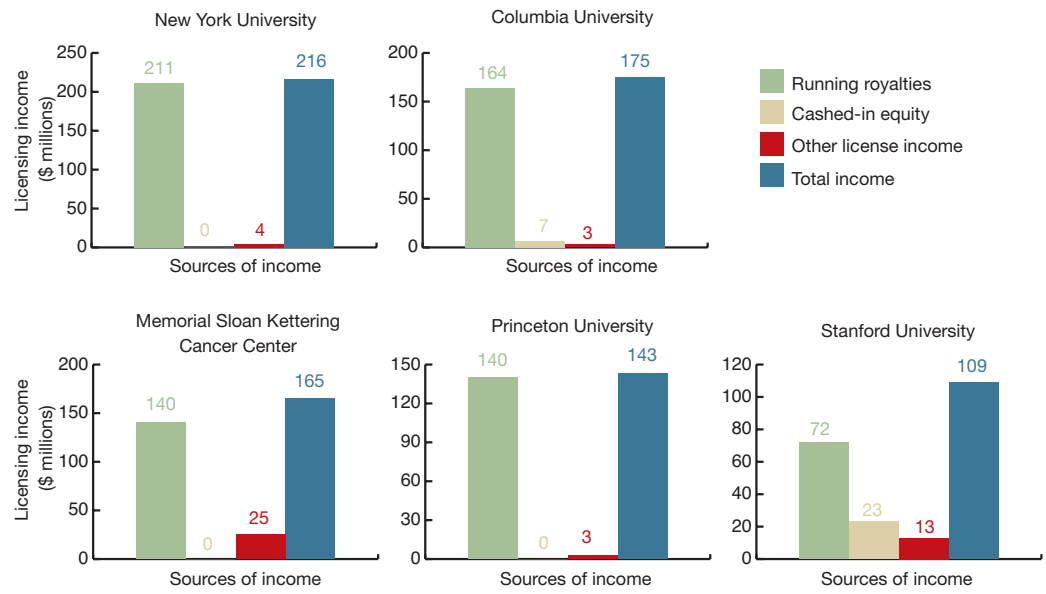

Figure 2 Breakdown of gross licensing income at the top 5 TTOs with running royalties. Source: 2014 AUTM Licensing Survey. 


\section{Box 1 Monetizing royalties and maximizing returns}

Academic institutions seeking to license assets should be aware that royalties can be monetized. Firms provide upfront payments to licensors in exchange for future royalty payments. This accelerates the licensor's receipt of compensation for this $\mathrm{IP}$ and helps remove risks associated with the royalty stream for licensors. Royalties can be acquired in their entirety as part of a full monetization (Fig. 6a). Alternatively, licensors may elect to sell a portion of their royalties as part of a partial monetization (Fig. 6b). Transactions are typically done on approved products but can also be completed on select pre-approval drug candidates with strong, late-stage clinical data. Monetization also allows licensors to offload future clinical, regulatory, and commercial risks, including health technology assessment, drug pricing, payor reimbursement, and the competitive risks associated with the arrival of new therapies. Over the past decade, royalty monetization has evolved into a routine form of financing with a competitive cost of capital.

In negotiating agreements, licensors may also tailor terms to emphasize an early return on investment or a greater cumulative return on investment over time (Fig. 6 and Table 2). For example, a licensor negotiating increased (doubled) milestones and a pre-approval royalty buyout option with the licensee (even at a seemingly high valuation of $\$ 20$ million) succeeds in receiving more income earlier (Fig. 6c). Ultimately, however, such a deal results in a substantially lower cumulative payment ( $\$ 190$ million versus $\$ 388$ million) to the licensor than if royalty payments are retained (Fig. 6 d). Preserving royalty payments in license agreements is almost always advantageous for the licensor because the economic potential of licensed technology is rarely clear at the time a license agreement is executed, or even

d

\section{a}

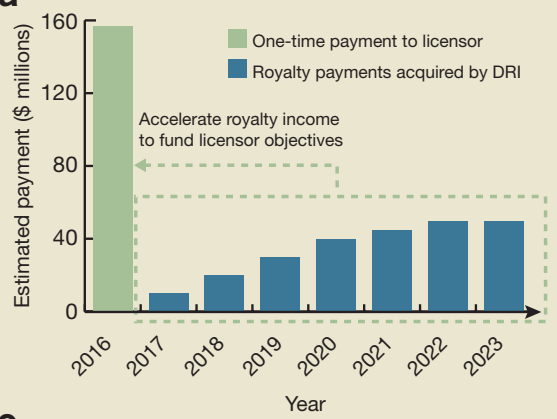

b

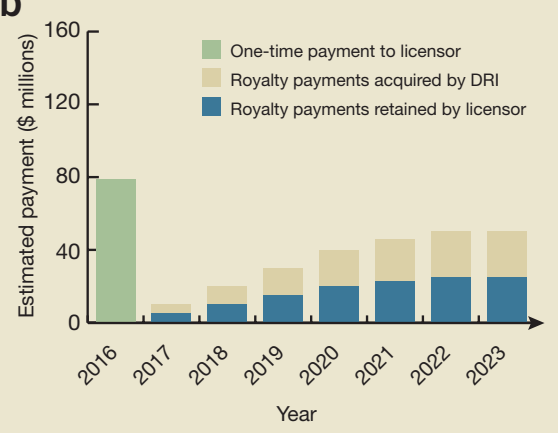

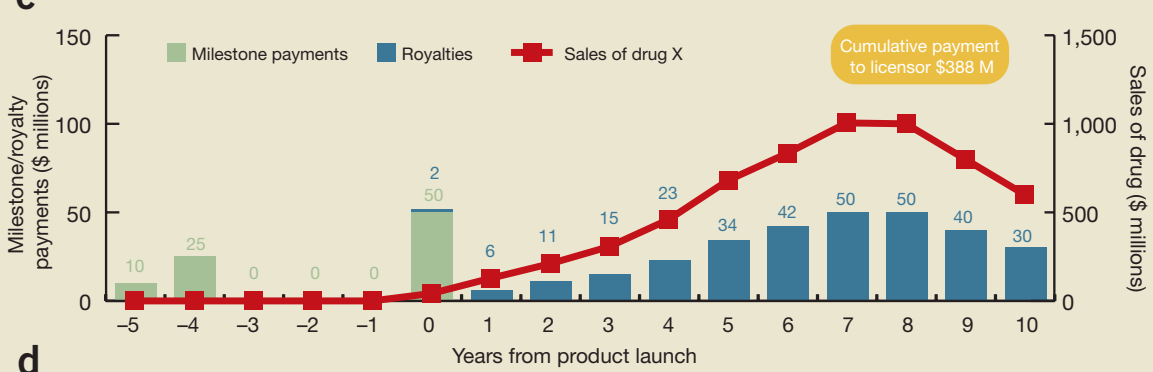
Years from product launch

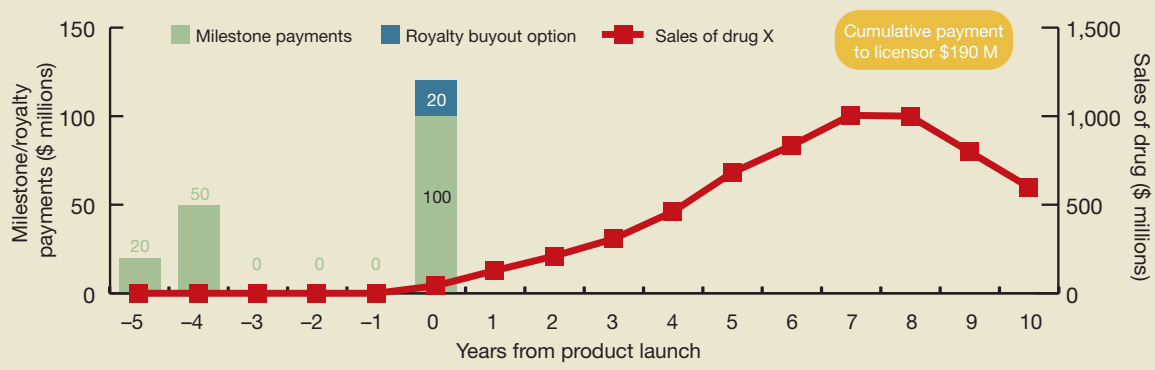

Figure 6 Structuring of licensing and royalty monetization deals to accelerate payments, maximize return to the institution, and/or mitigate asset risk: conceptual examples. (a) Deal with full monetization of asset. (b) Deal with partial monetization of asset. (c) Payout to institution with mixture of milestones and royalties (yields $\$ 388$ million to licensor over 15 years). (d) Payout to institution with higher milestones and royalty buyout option (yields $\$ 190$ million to licensor over 15 years).

\begin{tabular}{|c|c|c|c|c|}
\hline Deal structure & Milestones (development and regulatory approval) & Royalties & Royalty buyout option? & Cumulative payment to licensor \\
\hline \multirow{3}{*}{$\begin{array}{l}\text { Maximized value: combination of } \\
\text { milestones and royalties }\end{array}$} & $\$ 10$ million for phase 1 & \multirow{3}{*}{$\begin{array}{l}5 \% \text { of net } \\
\text { sales }\end{array}$} & \multirow[t]{3}{*}{ No } & \multirow[t]{3}{*}{$\$ 388$ million } \\
\hline & $\$ 25$ million for phase 2 & & & \\
\hline & $\$ 50$ million for phase 3 and approval & & & \\
\hline \multirow{3}{*}{$\begin{array}{l}\text { Lost value: higher milestones, } \\
\text { no royalties (pre-approval royalty } \\
\text { buyout option) }\end{array}$} & $\$ 20$ million for phase 1 & \multirow{3}{*}{$\begin{array}{l}5 \% \text { of net } \\
\text { sales }\end{array}$} & \multirow{3}{*}{$\begin{array}{l}\text { Yes; } \$ 20 \text { million } \\
\text { (following phase } 3 \\
\text { data) }\end{array}$} & \multirow[t]{3}{*}{$\$ 190$ million } \\
\hline & $\$ 50$ million for phase 2 & & & \\
\hline & $\$ 100$ million for phase 3 and approval & & & \\
\hline
\end{tabular}

licensee will need to license broad IP to bring a product to market. This may necessitate payment of royalties to third parties, leading to royalty stacking. Such royalty stacking may erode the profitability of a product and limit its commercial feasibility, and should be addressed through contractual options that limit its potential impact.

Depending on the jurisdiction of the licensor and licensee, withholding tax may be an issue, and should be addressed. Withholding should occur only if required by law, and the licensee should be required to assist in recovering withheld taxes if possible. Royalties are typically calculated as a percentage of net sales. A well-drafted license agreement will specify the exact types of expenses and deductions that are permitted, as these will effectively 
reduce the royalty payments made to the licensor.

The royalty rate itself will be determined by multiple factors such as precedent deals and market conditions, the stage at which the technology is licensed, the scope of license, therapeutic area, the innovation level associated with the technology, as well as future development cost considerations ${ }^{5}$. Analogs of comparable transactions, if available, based on similar technology, stage of development and commercial potential can be useful in negotiating royalty rates and transactions. The primary challenge with this approach is the confidential nature of prior deals and the comparability of the licensed technology.

Perhaps counterintuitively, maximizing the royalty rate may not always be in the best interests of the licensor. If the royalty rate is exceptionally high, it may serve as a disincentive to the licensee because the profit associated with the commercial product will be negatively affected by the royalty. An exceptionally high royalty rate may also incentivize a licensee to develop technology that works around the IP defined in the license agreement. A straightforward way to address this potential is to structure a tiering threshold for royalty payments. As well, minimum running royalties are often included in license agreements, and serve as an incentive to the licensee to develop and commercialize the IP.

Sales tiering can be used to scale royalty rates up or down as product sales increase beyond pre-defined volume thresholds. Defining how these thresholds are to be calculated is important to avoid possible disagreements regarding calculation. For example, royalty tiering based on worldwide sales or a regional breakout can materially affect royalties received.

We have also observed instances in which licensees demand that royalty buyout options be included in license agreements. A licensee

Generating running royalties Generating $>\$ 1 \mathrm{M}$ in licensing income

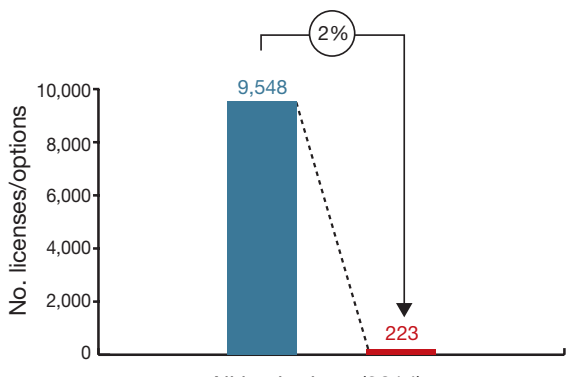

All institutions (2014)

Figure 3 Number of licenses/options generating running royalties versus number of licenses/ options generating $>\$ 1$ million in annual licensing income. Source: 2014 AUTM Licensing Survey. may insist, for example, for an option to buy out or extinguish a royalty for a pre-defined sum once a drug candidate enters a certain phase of clinical development, or upon regulatory approval. We caution academic institutions and other licensors against agreeing to this option for two reasons. First, this option removes the potential for long-term compensation from a resulting royalty. Second, the upfront payment negotiated as part of the buyout option is almost certainly lower than the value of the royalty stream at the time. It is very challenging to value the royalty interest at the time a license agreement is negotiated, and the payment negotiated is thus typically an arbitrary token sum.

In the event that a licensee sublicenses out the IP, the original licensor should be compensated. The original licensor typically receives a royalty on product net sales made by the licensee's sublicensee. In addition, the original licensor may receive a percentage of all other economic incentives (e.g., upfront payments, milestone payments) that the sublicensee pays the licensee in that subsequent transaction. Alternatively, the original licensor may elect to receive a percentage of all sublicensing revenue. Because of the importance of partnerships and alliances in the life sciences sector, it should be assumed that a licensee may need to sublicense a product to ensure its commercial success in certain geographic or therapeutic markets. Including thoughtful provisions related to sublicensing will maximize the value of the IP, even if it is used by a party other than the original licensee.

Administrative factors. Assuming a product is commercialized internationally, currency considerations become extremely important. For clarity, license agreements should specify the currency in which royalties are to be paid. For example, if royalties are paid in US dollars, the value of the local currency in which the product is sold will dramatically affect the value of royalties ultimately received by the licensor. The licensor and licensee need to agree on a date on which any foreign currency conversions are to be calculated, and what the basis of the currency conversion will be $\mathrm{e}^{7}$.

Frequency of payment, typically quarterly or biannually, should be clearly defined. More frequent timing is preferable, as funds can be deployed against strategic projects or reinvested more rapidly.

Obligations should outline who has responsibility for patent maintenance and prosecution. The licensor typically takes on this responsibility, and may be reimbursed

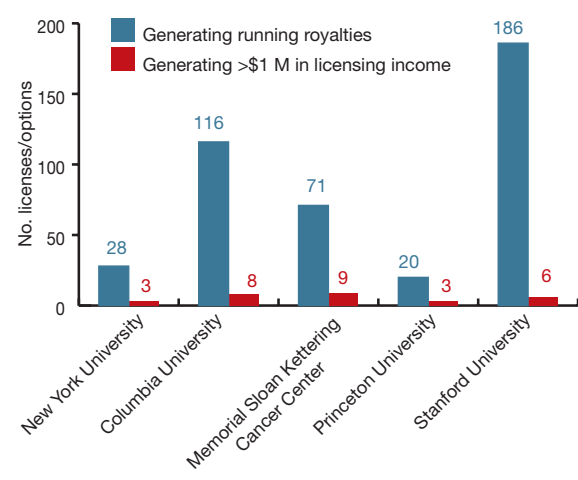

Figure 4 Number of licenses/options yielding income at five leading academic institutions. Source: 2014 AUTM Licensing Survey.

by the licensee for certain expenses incurred in fulfilling this obligation. The licensee may have a different view of the IP than the licensor. If it is key IP, the licensee and licensor will both be incentivized to maximize its potential. If the licensee does not view it as key IP and is only licensing it to ensure freedom to operate, incentives are different and the licensee may be less motivated to develop the technology. In the latter case, licensors should strive to maintain control over patent prosecution. Similarly, responsibility for any mechanisms, processes or procedures that may extend the life of licensed IP (and associated economic compensation), such as patent term extensions or supplementary protection certificates, should be clearly specified.

The licensor should include language that ensures the licensee will actually make reasonable or even best efforts to commercialize the licensed IP. As such, the licensee will be held to a particular standard and incentivized to develop the licensed IP. The licensor will have some comfort that its IP will not be de-prioritized or 'shelved' while the licensee advances other initiatives.

Attention to administrative considerations, such as the content of royalty statements, termination rights, and audit rights, can save time and money and prevent disagreements in the future. Licensors should request as much information as possible on royalty statements to facilitate validation of royalty payment calculations, including country-by-country product sales information. Licenses should in particular specify that regular, detailed development and even commercialization reports be provided to the licensor (ideally in writing and also in person, presented by a senior official of the licensee organization) to ensure that the licensee is working to advance the IP in every way possible.

A license agreement should outline the conditions under which the licensor or licensee 

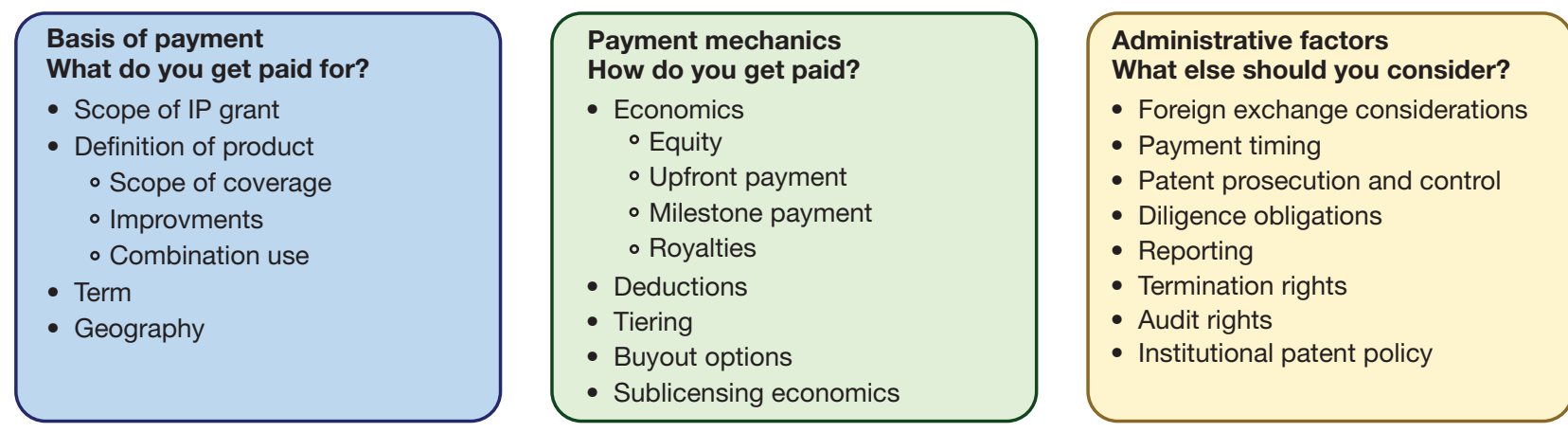

Figure 5 Key factors when considering royalty-bearing licenses. The factors that drive how much value can be obtained include the basis of the payment; payment mechanics; and administrative factors.

can terminate the agreement. As noted above, license agreements should be designed so that both parties have an interest in and are incentivized to develop the relevant IP. Termination rights are typically relevant in the case of a breach of contract. For example, a licensee challenging a patent may be grounds for termination of the license agreement. A license agreement should contemplate the possibility that a licensee may declare bankruptcy or undergo a change of control. Either situation may lead to a breach of contract and constitute grounds for termination of the license agreement.

It is also customary for licensors to have audit rights, with the licensee covering audit fees in the event underpayment exceeds some pre-negotiated threshold (e.g., 5\%, so as to be fair to licensees as well). Audit rights help to detect and then prevent underpayment, and they also enable the licensor to recover lost payments in the event of a dispute. For example, licensors will want to ensure that they can validate that they were paid royalties on a product that was manufactured but not sold before the expiry of any royalty-bearing patents.

Academic institutions will want to ensure they have a robust patent or IP policy in place as a matter of best practice. They typically split royalties among inventors, their department, as well as the institution itself, but the precise nature of the split varies. Institutions should have a clearly accessible policy outlining how economics are split. We have encountered numerous instances where a policy is amended and TTOs and inventors are left unsure about which patent policy governs patents filed or granted before the policy was amended. This situation is made even more confusing when inventors are no longer working for the institution, which is frequently the case.

Finally, academic staff should also be encouraged to disclose new inventions to their TTO before publicly disclosing such information to facilitate filing of patent applications. Inventions that are publically disclosed before patenting become part of the public domain and cannot be patented retroactively.

We illustrate some of the flexibility of royalties as an economic tool in Box 1 (Fig. 6 and Table 2). Academic institutions can not only tailor agreements so that milestone and royalty payments are fine-tuned in accordance with their financial needs, they can also monetize assets early through sales to firms that buy royalty rights.

\section{Conclusions}

Effective license agreement design and drafting facilitates successful academic technology commercialization. Although trade-offs exist between upfront payments and downstream royalties, the historical evidence shows that royalty payments are a key value driver of economic success at leading academic institutions. Moreover, agreements focusing on royalty-related economics best align the incentives of the licensor and licensee, maximize the long-term value of IP and streamline negotiations with licensees, while also preserving options for downstream monetization.

\section{ACKNOWLEDGEMENTS}

The authors would like to thank C. Shepherd, G. Margolis, P. Alloway, and P. Savard for their feedback on the manuscript.

\section{COMPETING FINANCIAL INTERESTS}

The authors declare competing financial interests: details are available in the online version of the paper (doi:10.1038/nbt.3624)

1. Wong, S.C.K. et al. Nat. Biotechnol. 33, 232-236 (2015).

2. Jones, A. Nat. Rev. Drug Discov. 6, 711-719 (2007).

3. AUTM licensing survey, FY2014 (The Association of University Technology Managers, Oakbrook Terrace, Illinois, Copyright 2004)

4. Huggett, B. Nat. Biotechnol. 32, 1184-1191 (2014).

5. Finch, S. Curr. Issues Trends. 7, 1-11 (2001).

6. Cameron, D.M. \& Borenstein, R. Key aspects of IP license agreements. (2003) http://www.jurisdiction. com/lic101.pdf.

7. Holmes, M.S. Patent Licensing: Strategy, Negotiation, Forms. (Practising Law Institute, 2000).

8. Brulotte v. Thys, 379 US 29 (1964).

9. Kimble et al. v. Marvel Enterprises, LLC, 576 US (2015). 